\title{
The Employer as a Necessary Party to Voluntary Settlement of Work Assignment Disputes Under Section $10(\mathrm{k})$ of the NLRA
}

In Plasterers Local 79 v. $N L R B^{1}$ the Court of Appeals for the District of Columbia Circuit recently reversed a long standing Board practice by declaring that an employer is not a necessary party to a voluntary adjustment of a jurisdictional dispute under section $10(\mathrm{k})$ of the National Labor Relations Act. ${ }^{2}$ The Board promptly responded to the decision by reaffirming its position that employers must be parties to such adjustments. ${ }^{3}$ Despite the Board's non-acquiescence, the Plasterers decision introduces an unsettling element into the statutory procedures surrounding jurisdictional disputes.

The NLRA contains a special procedure to deal with disputes between two or more unions or labor groups claiming the right to perform the same work. Strikes resulting from such "work assignment" or "jurisdictional" controversies are made unfair labor practices by section $8(\mathrm{~b})$ (4)(D) of the NLRA. ${ }^{4}$ However, section $10(k)^{5}$ has been interpreted to

1 - F.2d -, 63 CCH Lab. Cas. I 10,998, 74 L.R.R.M. 2575 (D.C. Cir. 1970).

2 Section $10(\mathrm{k})$ provides:

(k) Whenever it is charged that any person has engaged in an unfair labor practice within the meaning of paragraph (4)(D) of section $8(\mathrm{~b})$, the Board is empowered and directed to hear and determine the dispute out of which such unfair labor practice shall have arisen, unless, within ten days after notice that such charge has been filed, the parties to such dispute submit to the Board satisfactory evidence that they have adjusted, or agreed upon methods for the voluntary adjustment of, the dispute. Upon compliance by the parties to the dispute with the decision of the Board or upon such voluntary adjustment of the dispute, such charge shall be dismissed.

29 U.S.C. \& I60(k) (1964).

3 Lathers Local 104, 186 N.L.R.B. No. 70 (1970).

4 Section $8(\mathrm{~b})(4)(\mathrm{D})$ provides:

(b) It shall be an unfair labor practice for a labor organization or its agents-

(4) (i) to engage in, or to induce or encourage any individual employed by any person engaged in commerce or in an industry affecting commerce to engage in, a strike or a refusal in the course of his employment to use, manufacture, process, transport, or otherwise handle or work on any goods, articles, materials, or commodities or to perform any services; or (ii) to threaten, coerce, or restrain any person engaged in commerce or in an industry affecting commerce, where in either case an object thereof is-

(D) forcing or requiring any employer to assign particular work to employees in a particular labor organization or in a particular trade, craft, or class, unless such employer is failing to conform to an order $a_{i}$ certification of the Board determining the bargaining representative for the employees performing such work.

29 U.S.C. § 158(b)(4)(D) (1964).

5 See note 2 supra. 
require that, prior to any determination of the unfair labor practice charge, the Board must conduct a hearing ${ }^{6}$ to determine the merits of the jurisdictional claim behind the dispute. ${ }^{7}$ Voluntary compliance with the Board's award will stay the $8(\mathrm{~b})(4)(\mathrm{D})$ proceeding. ${ }^{8}$ Alternatively, section $10(\mathrm{k})$ provides that if all the parties agree upon a settlement or a method of settlement within ten days after notice of the charge is filed then the $10(k)$ hearing is obviated and the underlying charge shall be dismissed. If a union refuses to comply with either a Board determination under section $10(\mathrm{k})$ or a voluntary settlement within the meaning of that section, the General Counsel for the NLRB will issue an 8(b) (4)(D) complaint ${ }^{9}$ against the offending labor group. ${ }^{10}$

Since the enactment of the statute, the Board has maintained that a "voluntary adjustment" will preclude further $10(\mathrm{k})$ proceedings only where the voluntary procedure includes both the disputing groups and the employer. ${ }^{11}$ Despite the rumblings of a few academics, ${ }^{12}$ neither the Board ${ }^{13}$ nor the federal courts ${ }^{14}$ had questioned this position until the Plasterers case.

6 The Board requires that there be reasonable cause to believe that an $8(b)(4)(D)$ violation has occurred before it will conduct a $10(k)$ hearing. See, e.g., Painters Local 243, 125 N.L.R.B. 136, 140 (1959); Operating Eng'rs Local 450, 115 N.L.R.B. 964, 967 (1956). See also Herzog v. Parsons, 181 F.2d 781 (D.C. Cir. 1950); 3 CCH LAB. L. REP. 5230.03 (1970). Cf. Ship Scaling Contractors Ass'n, 87 N.L.R.B. 92 (1949).

7 In other unfair labor practice cases, an unfair labor practice charge leads directly to the issuance of a complaint by the General Counsel under $\$ 10(\mathrm{~b})$ of the NLRA, 29 U.S.C. $\S 160$ (b) (1964). The complaint is followed by an adversary type proceeding under $\S 10$ (c), 29 U.S.C. $\$ 160$ (c) (1964).

8 Where voluntary adjustment machinery breaks down, a $10(\mathrm{k})$ hearing is not a prerequisite for an $8(\mathrm{~b})(4)$ (D) complaint. Lathers Local 2, 119 N.L.R.B. 1345 (1958).

929 C.F.R. \& 101.36 (1961). See also Lathers Local 2, 119 N.L.R.B. 1345, 1347 (1958).

10 There are other important statutory provisions concerning jurisdictional disputes. \$ 303(a) of the LMRA, 29 U.S.C. \$ 187(a) (1964), makes conduct which would violate $8(\mathrm{~b})(4)(\mathrm{D})$ the basis for a civil suit for damages and costs under 303(b), 29 U.S.C. § 187(b) (1964). § 10(1) of the NLRA, 29 U.S.C. $\$ 160(1)$ (1964), gives the NLRB the power to seek a temporary restraining order against conduct proscribed by $8(\mathrm{~b})(4)(\mathrm{D})$.

11 Lathers Local 104, 186 N.L.R.B. No. 70 (1970). See also Carpenters Local 1622, 139 N.L.R.B. 591, 594 (1962); Operating Eng'rs Local 450, 119 N.L.R.B. 1725, 1730-32 (1958); Plumbers \& Pipefitters Local 428, 108 N.L.R.B. 186, 195-98 (1954). In addition see the other authorities cited in the dissenting opinion of the Plasterers case, $63 \mathrm{CCH}$ Lab. Gas. If 10,993 , at 19,188 n.l.

12 O'Donoghue (counsel on the brief for petitioner in Plasterers), Jurisdictional Disputes in the Construction Industry Since CBS, 52 GEO. L.J. 314, 332 (1964); Sussman, Section 10(k): Mandate for Change? 47 B.U.L. REv. 201, 209 (1967); cf. Note, Work-Assignment Disputes Under the National Labor Relations Act, 73 HARv. L. REv. 1150, 1156 (1960). 13 See authorities cited note Il supra.

14 See Operating Eng'rs Local 450 v. Elliot, 256 F.2d 630, 636 (5th Cir. 1958). In addition see the other authorities cited in the dissenting opinion of the Plasterers case, $63 \mathrm{CCH}$ Lab. Cas. If 10,993, at 19,189 n.2. But cf. Penello v. Sheet Metal Workers Local 59, 195 F. Supp. 458, 466 (D. Del. 1961).

Under the Railway Labor Act the courts have never questioned the employer's right to 
The case involved a dispute between a plasterers union ${ }^{15}$ and a tilesetters union ${ }^{16}$ over the right to apply a coat of mortar to walls as a preliminary step to tiling. Both unions were bound ${ }^{17}$ to comply with jurisdictional determinations rendered by the National Joint Board for the Settlement of Jurisdictional Disputes, ${ }^{18}$ an arbitration panel established by the Building Trades Department of the AFL-CIO. The employers in the case ${ }^{19}$ had not agreed to accept any such award in lieu of an NLRB determination under 10(k). The Joint Board heard the dispute without making the employer a party and awarded the job to the plasterers. The employers and the tilesetters refused to yield the work to the plasterers, who thereupon began to picket the job sites. The employer filed unfair labor practice charges under section $8(b)(4)(D)$, which resulted in a $10(\mathrm{k})$ award in favor of the tilesetters ${ }^{20}$ and a subsequent $8(\mathrm{~b})(4)(\mathrm{D})$ order against the plasterers ${ }^{21}$ for refusing to comply with the NLRB determination. The District of Columbia Circuit reversed the Board on the ground that the Joint Board award precluded further NLRB proceedings. ${ }^{22}$

be a party to the jurisdictional dispute proceedings before the National Railroad Adjustment Board. See Transportation Union v. Union Pac. R.R., 385 U.S. 157 (1966). However, there are strong statutory indications that Congress intended for employers to be parties to such proceedings under the RLA which are not present in the NLRA. See Railway Labor Act, 45 U.S.C. §§ 153, First (a)(g)(j)(o)(p) (1964).

15 Plasterers Local Union No. 79, Operative Plasterers and Cement Masons International Association, AFL-CIO.

16 Tile, Terrazzo, and Marble Setters Local Union No. 20, Bricklayers, Masons, and Plasterers International Union of America, AFL-CIO.

17 All unions affiliated with the Building and Construction Trades Department, AFL$\mathrm{GIO}$, are bound to comply with Joint Board determinations of jurisdictional disputes. Const. of Building \& Trades Dep'T, AFL-CIO, art. X (1961). See Lathers Local 9, 113 N.L.R.B. 947 (1955). The operation of article $X$ and the organization of the Joint Board are discussed briefly in Plasterers, 63 CCH Lab. Cas. If 10,993, at 19,181.

18 The Joint Board is discussed in Atleson, The NLRB and Jurisdictional Disputes: The Aftermath of CBS, 53 GEo. L.J. 93, 130 (1964); O’Donoghue, supra note 12, at 329; Rains, Jurisdictional-Dispute Settlements in the Building Trades, 8 LAB. L.J. 385, 390-94 (1957); Sussman, supra note 12, at 225.

19 The dispute submitted to the Joint Board involved a controversy at a job site where Southwestern Construction Co. was the general contractor and Texas State Tile and Terrazzo, Inc., was the subcontractor in charge of the disputed work. The $8(b)(4)(D)$ charge also included picketing at another job site where the work was under Martini Tile and Terrazzo Co.

20167 N.L.R.B. 185 (1967).

21172 N.L.R.B. No. 77 (1968).

22 Although the Plasterers decision purported to deal only with the employer's right to be a party to voluntary adjustment decisions, the opinion has important ramifications with regard to the right of employers to be heard in $10(\mathrm{k})$ hearings. Presumably, if an employer is not a necessary party to a voluntary adjustment, then he likewise is not a necessary party in an NLRB proceeding. However, the majority opinion suggests that this result may be avoided by distinguishing "parties to the dispute" (the unions), which are necessary for voluntary adjustment, from "parties to the $10(\mathrm{k})$ proceeding" (presumably 
The court's decision seems to rest on two somewhat overlapping bases, both of which involve the question of congressional intent. On the one hand, the court suggested that Congress specifically did not intend employers to be parties to $10(\mathrm{k})$ proceedings; consequently, the Joint Board determination satisfied the requirements of $10(\mathrm{k})$ since the only rightful parties to a $10(\mathrm{k})$ hearing, the unions, were also parties to the voluntary determination. The court's other line of reasoning looked to a more generalized intent. The majority held that $10(\mathrm{k})$ procedures were designed solely to protect "neutral employers," whose only valid interest is the swift resolution of the dispute rather than the merits of the controversy. The court indicated that the Joint Board decision protected this interest as well as did NLRB proceedings. ${ }^{23}$ This comment will examine these arguments and the premises, legislative history, and policy considerations upon which they were based.

\section{Narrow Intent: Was the Employer InTENded to be a Party?}

The majority opinion in Plasterers asserted that Congress specifically did not intend that the employer be a necessary party to $10(\mathrm{k})$ proceedings or to voluntary adjustments under that section. ${ }^{24}$ The court ascertained this intent from two sources-the legislative history and the wording of the Act.

The relevant legislative history contains two types of references which the court found persuasive. First, there are "definitional" remarks which describe a jurisdictional dispute as a controversy between two or more unions. ${ }^{25}$ However, such remarks merely reflect the truism that a jurisdictional dispute has as its essence interunion controversy. These axiomatic observations certainly do not compel the inference that Congress intended that the employer not be heard on the merits of the dispute.

A second type of commentary surrounding $10(\mathrm{k})$ suggests that a primary purpose of the section was to encourage the development of private interunion machinery to resolve work assignment controversies. ${ }^{26}$ Senator Morse cited the practice of the War Labor Board

the employer and the unions). 63 CCH Lab. Cas. I 10,993, at 19,182. The court cites no authority for this distinction and there is no support for it in either the statute or the legislative history.

$23 I d$. at 19,187-88. It is significant to note that the Joint Board determination had not resulted in a resolution of the dispute because the tilesetters had refused to comply with the determination.

24 Id. at 19,182 .

2593 Cong. Rec. 1890 (1947), II NLRB, Legislative fistory of the LABor ManageMENT RELATIONS ACT, 1947, 951 (1948) [hereinafter cited as LEG. Hist.] (remarks of Senator Morse); H.R. REP. No. 510, 80th Cong., 1st Sess. 57 (1947), I LEG. HisT. 561 (1947), cited by the court, $63 \mathrm{CCH}$ Lab. Cas. If 10,993, at 19,184.

2693 CoNG. REC. 1911 (1947), II LEG. HIsT. 983 (remarks of Senator Morse), cited by the 
during World War II for its effectiveness in encouraging interunion agreement:

$[W]$ e would give the union leaders involved in a jurisdictional dispute 24 hours to proceed to settle the dispute without a work stoppage, and upon their failure to do so we would appoint an arbitrator whose decision would be final and binding.

What I wish to stress is the remarkable compliance we obtained so far as the quick settlement of jurisdictional disputes was concerned $\ldots . .^{27}$

The War Labor Board practice was cited primarily as an example of the efficacy of a statutory incentive to voluntary settlement; there was no express consideration of the employer's role in jurisdictional disputes under either the wartime emergency practice or the proposed legislation.

It is certainly consistent to have the objective of encouraging interunion settlements while at the same time intending that no such settlement exclude the employer. Commentators tend to support the court's position as to what Congress would have done had it faced the issue squarely. ${ }^{28}$ But the more accurate view would seem to be that, as expressed in the Plasterers dissent, "the members of Congress just did not address themselves to the point." 29

Similar criticisms can be leveled at one of the court's efforts to divine congressional intent from the wording of $10(\mathrm{k})$. The majority relied heavily on the failure of Congress to name the employer as a necessary party to a $10(\mathrm{k})$ proceeding:

Congress could have written $\S 10(\mathrm{k})$ so that the employer would be a necessary party to a procedure for voluntary settlement by requiring agreement on such a procedure by both the parties to the unfair labor practice charge and the parties to the underlying dispute out of which that charge arises. ${ }^{30}$

But Congress also could have written the section so as to limit the necessary parties specifically to the rival labor groups involved. Instead,

court, 63 CCH Lab. Cas. If 10,993, at 19,184-85. See also S. (MIN.) REP. No. 105, 80th Cong., Ist Sess. pt. 2, at 18-19 (1947), I LEG. HIST. 480-81; 93 CoNG. REg. 6610 (1947), II LEG. HIST. $1554-55$.

2793 CoNc. Rec. 1910-11 (1947), II LEg. Hist. 983, cited in Sussman, supra note 12, at 210-11. The first paragraph is quoted in the Plasterers opinion. $63 \mathrm{CCH} \mathrm{Lab}$. Cas. I 10,993, at 19,184. See also U.S. Nat'L War LABOR Board (1942-45), Termination Report vol. I, at 71-80 (1945); S. PODOlsky, Gume to WAR Labor BoArd Policy 2 (2d ed. 1945).

28 See authorities cited note 12 supra.

$2063 \mathrm{CCH}$ Lab. Cas. I 10,998, at 19,190 (MacKinnon, C.J., dissenting).

30 Id. at 19,182 . 
the legislative process produced a more ambiguous statute, which arguably is subject to either interpretation.

The court's second statutory construction argument is not as easily dismissed. The court noted a lack of mutuality in the NLRB interpretation of the statute. ${ }^{31}$ Although $10(\mathrm{k})$ penalizes the losing union by subjecting it to $8(\mathrm{~b})(4)(\mathrm{D})$ charges if it strikes instead of complying with the Board award, no similar sanction exists against the employer who chooses to disregard the $10(\mathrm{k})$ decision. ${ }^{32}$ The court concluded that " $[\mathrm{t}]$ he fact that the employer is not bound by a $10(\mathrm{k})$ determination of the Board is persuasive evidence that Congress did not intend a voluntary procedure for adjustment to be held inadequate because the employer is not bound [by the result of the voluntary adjustment]." 33 However, the lack of mutuality which the court perceived is more apparent than real. The legal effect of a $10(\mathrm{k})$ award on the unions is very limited. Although they are precluded from raising the specific defense of right to the work in question, the unions still may be exonerated of $8(\mathrm{~b})(4)(\mathrm{D})$ charges. While the Board award cannot be challenged in an unfair labor practice hearing, ${ }^{34}$ the findings and conclusions in a $10(\mathrm{k})$ proceeding are not res judicata in the later $8(\mathrm{~b})(4)(\mathrm{D})$ determination $^{35}$ as far as the existence of an unfair labor practice is concerned. Both parties can put in new evidence at the $8(\mathrm{~b})(4)(\mathrm{D})$ stage; ${ }^{36}$ and, the two proceedings have different standards of proof. "In a section $10(\mathrm{k})$ proceeding the Board need find only that there is reasonable cause to believe that an $8(\mathrm{~b})(4)(\mathrm{D})$ violation has occurred; ${ }^{37}$

31 Id. at $19,188,19,182$.

32 The employer is not required to give the work in question to the group that wins the $10(\mathrm{k})$ award, but if that union strikes the employer to enforce the award, then the employer cannot obtain relief under $8(\mathrm{~b})(4)(\mathrm{D})$.

It has been questioned whether a union winning an award under $10(\mathrm{k})$ could be held liable under 303. See Note, Work-Assignment Disputes Under the National Labor Relations $A c t, 73$ HARv. L. REv. 1150, 1160 (1960). A Board determination under 10(k) or $8(\mathrm{~b})(4)(\mathrm{D})$ is not a condition precedent for a 303 action. Longshoremen v. Juneau Spruce Corp., 342 U.S. 237 (1952); Public Constructors, Inc. v. Local 400, IBEW, 55 CCH Lab. Cas. I 11,883 (D.N.J. 1967). The 303 trial is usually before a jury; Board determinations are not given res judicata effect. Taube Elec. Contractors, Inc. v. Local 349, IBEW, 261 F. Supp. 664, 665 (S.D. Fla. 1966).

Conceivably an employer's noncompliance could be the basis for an unfair labor practice charge against the employer under $8(\mathrm{a})(1),(2),(3)$, or $(5)$, but the Board has never considered such noncompliance to violate these sections.

3363 CCH Lab. Cas. I 10,993 , at 19,182.

34 Cleveland Stereotypers Local 22, 160 N.L.R.B. 1184, 1186 (1966); Local 1291, ILA, 142 N.L.R.B. 257 (1963).

35 International Typographical Union, 125 N.L.R.B. 759, 761 (1959).

36 However, the evidence is often limited by stipulation to the record in the $10(\mathrm{k})$ proceeding. Compare Cleveland Stereotypers Local 22, 160 N.L.R.B. 1184, 1185 (1966), with International Typographical Union, 125 N.L.R.B 759, 761 (1959).

37 See note 6 supra. 
in an $8(\mathrm{~b})(4)(\mathrm{D})$ proceeding findings are based on a preponderance of the evidence." 38 Therefore, conceivably, the losing union in a $10(\mathrm{k})$ proceeding could win at the $8(\mathrm{~b})(4)(\mathrm{D})$ stage.

Admittedly it is very likely that continued union pressure in noncompliance with a $10(\mathrm{k})$ award will result in an 8(b)(4)(D) order where the union cannot claim the right to the work in question as a defense. However, the argument that the union is not bound by the $10(\mathrm{k})$ award is no more artificial and unrealistic than the court's argument that the employer is not bound. Although the employer has no direct legal obligation to comply with the $10(\mathrm{k})$ determination, his failure to award the work in question to the winning union has a very significant pragmatic effect. It allows the union to strike the employer to enforce the award without being prosecuted for $8(b)(4)(D)$ violations. The strike weapon can be unleashed immediately and its effect is often devastating. In one sense, therefore, the employer is legally affected by the award: he is deprived of the protection of $8(\mathrm{~b})(4)(\mathrm{D})$.

The cost of the strike weapon in jurisdictional disputes is indicated by the fact that in 1968, 379 work assignment strikes involving 43,900 workers cost employers 258,300 man-days of work. ${ }^{39}$ This figure does not begin to cover the secondary costs resulting from the refusal of other employees, customers, carriers, and other vital groups to cross picket lines.

Thus, the lack of mutuality in the Act can be viewed as a significant indicator of congressional intent to exclude employers as parties only if it is assumed that Congress shared the court's disregard of the practical realities of economic warfare. It is at least equally plausible that Congress did recognize the realities of the situation and bound the unions in order to equalize the coercive power between unions and employers. Under this view, any lack of mutuality in the statute is indicative of congressional concern for the interests of the employer caught in a cross-fire between unions. Such concern seems incompatible with an intent to exclude the employer from the one place where he can best protect his substantive interests-the $10(\mathrm{k})$ proceedings.

In short, the evidence is not convincing that Congress intended to exclude the employer as a party to a $10(\mathrm{k})$ proceeding. Since for all practical purposes the battle is won or lost at the $10(\mathrm{k})$ stage, employers as well as unions should be parties to such hearings, provided that they have valid interests to protect. The ultimate question then is whether

38 International Typographical Union, 125 N.L.R.B. 759, 761 n.5 (1959).

39 U.S. Bureau of Labor Statistics, Dep't of Labor, Buld. No. 1646, analysis of Work STOPpages, 1968, Table 5 (1970). The preliminary report for 1969 indicates even higher costs for that year. U.S. Bureau of LABor Statistics, Dep'T of Labor, Summary REPORT, WORK STOPPAGES IN 1969, Table 4 (1970). 
the employer has valid interests which are protected by a $10(\mathrm{k})$ hearing but not by a Joint Board determination.

\section{General Intent: Does the Employer Need to be a Party?}

The decision in Plasterers relied heavily on the assumption that Congress intended section $10(\mathrm{k})$ to benefit only "neutral" employers. ${ }^{40}$ Under this view the employer has no legitimate interest in the substance of the award; instead, his only cognizable concern is the swift resolution of the dispute. If the employer has no interest in the determination, then he does not need to be a party to the voluntary or statutory proceedings involved.

The court recognized that the literal language of the statute contains no requirement of employer neutrality:

The Taft-Hartley Act, though broad and unqualified in its terms, must be taken in light of its dominant purpose to protect "neutral" employers. ${ }^{41}$

The "dominant purpose" of sections $8(b)(4)(D)$ and $10(k)$ was established to the court's satisfaction ${ }^{42}$ by a sentence in the Supreme Court case of NLRB v. Radio Engineers Local 1212 (CBS): ${ }^{43}$

[A]nd the House Committee report on one of the proposals out of which these sections came recognized the necessity of enacting legislation to protect employers from being "the helpless victims of quarrels that do not concern them at all." 44

The fact that Congress intended to protect neutral employers does not require the inference that only neutral employers were considered worthy of protection. Indeed, other portions of the brief legislative history on this question suggest that all jurisdictional strikes were to be covered by $8(\mathrm{~b})(4)(\mathrm{D})$ and $10(\mathrm{k}),{ }^{45}$ and that the dominant purpose of the statute was the "elimination of the obstructions to the free flow of com-

4063 CCH Lab. Cas. If 10,993, at 19,187-88.

41 Id, at 19,187 .

$4263 \mathrm{CCH}$ Lab. Cas. I 10,993, at 19,183. But see the interpretation of this language in the Plasterers dissent, id. at 19,189 .

43364 U.S. 573, 580-81 (1961).

44 H.R. REP. No. 245, s0th Cong., Ist Sess. 23 (1947), I LEg. Hist. 314. The quote is taken somewhat out of context. The full sentence reads:

More often than not the employers are powerless to comply with the demands giving rise to the activities, and many times they and their employees as well are the helpless victims of quarrels that do not concern them at all.

The report went on to say that jurisdictional strikes were made unlawful under the proposed legislation. There was no indication of an intention to limit the provision to neutral employer situations.

4593 CoNG. REc. 4155 (1947), II LEg. Fist. 1046 (remarks by Senator Murray). 
merce" 46 and the preservation of industrial peace by affording quick relief from jurisdictional pickets. ${ }^{47}$ Aside from one unexplained reference by Senator Morse to employer "collusion," 48 the legislative history is completely void of any congressional indication that neutrality was intended to be a prerequisite for $10(\mathrm{k})$ standing.

The court also makes reference to the executive suggestions in President Truman's 1947 State of the Union Message ${ }^{49}$ as an indication of the objectives of Congress in enacting the Taft-Hartley Act. ${ }^{50}$ In a much cited phrase, Truman referred to the public and employers as "innocent bystanders who are injured by a collision between rival unions." ${ }_{11} \mathrm{He}$ then went on to condemn all jurisdictional strikes in no uncertain terms:

I consider jurisdictional strikes indefensible.

$\cdots \cdots$

... When rival unions are unable to settle such disputes themselves, provision must be made for peaceful and binding determination of the issues. ${ }^{52}$

Both the court decision and the Board practice provide a machinery for "peaceful and binding resolution of the issues." President Truman's remarks can provide a makeweight for either position depending on whether emphasis is placed on the word "innocent" or on the word "indefensible." If innocence connotes neutrality ${ }^{53}$ and was intended to be a prerequisite for relief, then perhaps Truman sought to proscribe only jurisdictional strikes against neutral employers. If all jurisdictional strikes are indefensible, then all disputes presumably were the target of the President's message. Probably both words were chosen for their emotive value rather than for an accurate description of the proposed legislative objective. The lack of significant legislative or executive com-

46 S. REP. No. 105, 80th Cong., lst Sess. 8 (1947), I LEg. Hist. 414.

47 Id. at 27, I LEG. HIST. at 433.

48 Senator Morse: "Does the Senator agree with me also, that the time has come when the public interest has a right to demand, in the absence of collusion on the part of the employer, that labor desist from economic action in jurisdictional disputes?" 93 CoNG. REC. 4256 (1947), II LEg. HIST. 1057.

$4963 \mathrm{CCH}$ Lab. Cas. I 10,993, at 19,183 n.14.

50 The weight to be accorded to this type of evidence of congressional intent may be questioned in view of the fact that the Taft-Hartley Act passed over President Truman's veto. However, the veto message makes no reference to the jurisdictional dispute provisions of the Act. See 93 CoNG. REc. 7485-88 (1947).

51 Id. at 136.

52 Id.

53 The most unscrupulous and most anti-union employer would be neutral in a jurisdictional dispute so long as he apportioned his malice evenly. Likewise it is difficult to characterize a legitimately interested employer as "guilty" of anything simply because he shows a preference as to what group performs certain parts of his business operation. 
ment on the neutrality issue makes it difficult to escape the conclusion that that problem was never really considered in the $10(\mathrm{k})$ context.

However, the court's position on employer neutrality did not rest solely on its view of the legislative history. The court also relied on the "Safeway doctrine"54 to support its views. ${ }^{55}$ In Safeway the NLRB held that an employer could not bring an $8(\mathrm{~b})(4)(\mathrm{D})$ action and obtain a $10(k)$ determination where the unions involved had voluntarily agreed which one would receive the job, that is, where there is no "real competition between unions or groups of employees for the work" 56 and the only actual dispute is between the employer and one union.

The court in Plasterers equated the situation where only one union claims a job with a case where two unions are bound to abide by a certain type of determination, saying that in both cases there is actual agreement between the two unions. ${ }^{57}$ Since the non-neutral employer does not receive the benefit of a $10(\mathrm{k})$ proceeding in the former case, the court decided that he should not receive it in the latter.

The court's extension of Safeway represents an extraordinary departure from the consistent attempts of the NLRB and the federal courts to narrow the doctrine. ${ }^{58}$ On policy grounds, Plasterers hardly presents a propitious moment to break with precedent. Obviously the court is correct in perceiving the employer's interest to be as strong in a "Safeway" situation, where one union is persuaded to disclaim the work, as in a "Plasterers" type controversy. The important distinction between the two cases is that in the former situation the parties are placed in what is in essence a collective bargaining position. To allow the Board

54 See Teamsters Local 107 (Safeway Stores, Inc.), 134 N.L.R.B. 1320 (1961). See also cases cited in the majority opinion in Plasterers, 63 CCH Lab. Cas. If 10,993, at 19,187.

55 $63 \mathrm{CCH}$ Lab. Cas. I 10,993, at 19,187.

56134 N.L.R.B. at 1323.

$5763 \mathrm{CCH}$ Lab. Cas. I 10,993, at 19,187.

58 Although the Safeway doctrine has never been overruled, the NLRB and the federal courts have interpreted the rule of that case very narrowly. One court refused to find a disclaimer where the inside union honored the outside union's picket line. Construction Employers Ass'n v. Operating Eng'rs Local 450, 427 F.2d 230, 233 (5th Cir. 1970). The Board has questioned a representative's authority to disclaim work. Millwrights Local 1113, 157 N.L.R.B. 996, 1002 (1966). Explicit disclaimers have been ignored or held nondispositive where the work in question was covered by a contract between the disclaiming union and the employer, Local 1291, ILA, 152 N.L.R.B. 676 (1965), enforced, 368 F.2d 107 (3d Cir. 1966), cert. denied, 386 U.S. 1033 (1967); Bricklayers Local 2, 152 N.L.R.B. 278, 282 (1965), or where the disclaiming union accepted pay for the work, Carpenters Local 1849 v. C.J. Montag \& Sons, Inc., 335 F.2d 216, 221 (9th Cir. 1964); see also Construction Employers Ass'n v. Operating Eng'rs Local 450, supra, at 234; Local 1291, ILA, supra, at 110, or where the disclaiming employees have continued to do the work after the disclaimer, Plumbers \& Pipefitters Local 525, 173 N.L.R.B. No. 208 (1968); see also Millwrights Local 1113, supra; Local 1291, ILA, supra, at 679-80. In sum, the NLRB and the federal courts have been quick to find the polarity necessary to present a "jurisdictional dispute." 
to hear a case within the Safeway doctrine would involve substantive interference with the bargaining process-an interference which is completely antithetical to the basic objectives of the NLRA. ${ }^{59}$ Yet, these reasons for restricting the availability of $10(\mathrm{k})$ are totally absent in Plasterers, where a real controversy between unions existed. In short, the court has stood the Safeway doctrine on its head. It has used a theory which starts from the premise that no real controversy exists ${ }^{60}$ to support a procedure which has an end result of eliminating the real controversy.

Upon this weak foundation of legislative history and precedent, the court concluded that giving preclusive effect to Joint Board determinations held without the employer best served the underlying policies of the Act. On the one hand, the Board through its injunctive power under section $10(l)$ could fully protect the neutral employer from labor strife until the Joint Board made its award; ${ }^{61}$ on the other hand, the court's holding would contribute to industrial peace by encouraging interunion settlements, since, contrary to the Board procedure, the losing union would be denied a "Iegal right to another bite at the apple in the $10(\mathrm{k})$ proceeding." 62 In this respect the court said that its result was buttressed by the strong federal labor policy in favor of arbitration. ${ }^{63}$

The real question is not whether the losing union should have an extra bite at the apple, but whether the first bite was ingestible; not whether arbitration is desirable, but who should be a party to the arbitration. If industrial peace were the only value to be protected, the legislature could conceivably obtain a zero level of disruption simply by prohibiting all challenges to employer awards. Thus, the argument comes full circle. The court uses its initial premise-that $10(k)$ was intended solely for neutral employers whose only legitimate concern is with the resolution of work assignment controversies, as opposed to the merits of the underlying claims-as a reason for its result-a procedure which provides for quick and final resolution of the dispute. The basic issue remains unresolved: should protection of the statute be reserved for neutral employers?

There are strong reasons against reading a neutrality requirement into the statute. As a practical matter, few employers are totally unconcerned with what group of employees performs the various jobs involved

59 See H.K. Porter Co. v. NLRB, 397 U.S. 99 (1970); NLRB v. Insurance Agents Int'1 Union, 361 U.S. 477, 487 (1960); NLRB v. American Nat'l Ins. Co., 343 U.S. 395, 404 (1952).

60 The Safeway doctrine has been used by the Board only to establish whether a jurisdictional dispute in fact exists. See, e.g., Carpet, Linoleum \& Soft Tile Layers Local 1905, 143 N.L.R.B. 25I, $255-56$ (1963); Lathers Local 328, 139 N.L.R.B. 598 (1962); Sheetmetal Workers Local 272, 136 N.L.R.B. 1402 (1962).

6129 U.S.C. \& 160(1) (1964).

$6263 \mathrm{CCH}$ Lab. Cas. I 10,993, at 19,186.

63 Id. at 19,191, citing Boys Mkts., Inc. v. Retail Clerks Local 770, 398 U.S. 285 (1970). 
in their business operations. Although employer partiality can be spawned by illicit considerations such as racial bias, ${ }^{64}$ the desire to avoid dealing with the proper bargaining representative of his employees, ${ }^{65}$ or the desire to utilize a company dominated union, ${ }^{66}$ legitimate criteria concerning the quality and efficiency of production, wage costs, and the stability of labor relations are more common sources of employer preference.

Consider as a blatant example the plight of a manufacturer struck by plumbers desiring work in precision tool making presently assigned to tool and die makers, or a painting contractor besieged by masons wanting jobs as painters. An employer in such a situation may be more in need of statutory protection than a completely neutral employer because he is equally hard hit by the jurisdictional strike and has more to lose by capitulation.

In practice the merits of the competing groups are rarely so disparate. However, even between well qualified competitors the employer's interests are significant. For example, assume that routine electrical maintenance work is claimed by both the electricians union and the maintenance workers union. An employer faced with this choice could legitimately prefer either union. The electricians are presumably more skilled and therefore more expensive, but their labor may be superior even on routine jobs. If the employer currently has some employees represented by each union in his plant, he may wish to give the work to the less busy group or the group closest to the work in order to avoid overtime, wasted hours, or interruption of the general flow of specific operations. He may be concerned about the mix of skills in his plant or on a particular shift, especially where a large volume of skilled or unskilled work is expected at a later date, or where there is a general scarcity of certain skills in the labor market. Assignment to one union may involve layoffs with corresponding unemployment benefit payments and office administrative costs. Eliminating the jobs of senior employees in high labor grades can involve collateral costs under contracts which give laid-off employees a right to displace lesser paid junior employees in lower labor grades. Furthermore, the award can have severe repercussions on labor-management relations. One union may be easier to deal with or more reliable; ${ }^{67}$ or, increasing the jobs done by one bargaining unit may complicate collective bargaining.

64 The use of racial considerations in employment practices is proscribed by Title VIr of the Civil Rights Act of 1964, 42 U.S.C. $\S 2000 \mathrm{e}$ to $\$ 2000 \mathrm{e}-15$ (1964).

65 A duty to bargain with representatives of his employees is placed on the employer by $\S \S 8(a)(1)$, (5) of the NLRA, 29 U.S.C. $\$ \S 158(a)(1)$, (5) (1964).

66 An employer's domination of or interference with any labor organization of his $\mathrm{em}$ ployees is prohibited by $\S \S 8 \mathrm{a}(1)$, (2) of the NLRA, 29 U.S.C. $\S \S 158(a)(1),(2)$ (1964). 
In sum, any change in present job allocation may involve considerable costs. It is significant to note in this respect that the great majority of jurisdictional disputes occur in the construction industry, ${ }^{68}$ which is characterized by closely figured bids with narrow profit margins. ${ }^{69}$ These margins can quickly be turned into deficits where forced work assignment changes involve any of the aforementioned costs. In fact, it could be argued that to inflict these substantial costs without allowing the employer to be heard is a denial of the employer's constitutional right to due process. ${ }^{70}$

The Joint Board is hardly an ideal forum in which to advance these important employer interests. Although it is composed of both union and employer representatives, ${ }^{71}$ its decisions tend to reflect purely union interests. In structuring its awards to best serve the interests of the constituent members of the Building Trades Department, the Joint Board gives controlling weight to prior Joint Board decisions of record and interunion agreements of record. ${ }^{72}$ In the absence of such decisions

67 Discrimination on the basis of union membership is made an unfair labor practice by $\S 8(a)(3)$ of the NLRA, 29 U.S.C. $\$ 158(a)(3)(1964)$.

68 See generally $\mathrm{K}$. STRAND, JuRisdictional Disputes in Construction: The Causes, the JOINT BOARD, AND THE NLRB (1961).

69 See note 77 infra.

70 The constitutional argument is that deciding an employer's substantive rights at a proceeding to which he is not a party is a denial of the employer's right to due process. Clearly a Joint Board decision which legally bound the employer would violate due process if the employer had not been made a party to the proceeding. See Shields v. Utah Idaho Cent. R.R., 305 U.S. 177, 182 (1938); Brandt v. Hickel, 427 F.2d 53, 56 (9th Cir. 1970). The fact that the decision has very strong practical, if not legal, effects might bring the employer within these cases. Cf. Sun Oil Co. v. Humble Oil \& Ref. Co., 88 F. Supp. 658, 663 (S.D. Tex. 1950). Authority in the labor law area is sparse. Cf. NLRB v. Mackay Co., 304 U.S. 333, 351 (1938). But cf. Marine Eng'rs Beneficial Ass'n v. NLRB, 202 F.2d 546, 549 (3d Cir. 1953) (suggesting that the right of a charging party to a hearing may arise only after the NLRB issues a complaint).

A second possible constitutional problem involves delegation of governmental power. It is arguable that where a private board is allowed to render a final decree which precludes further administrative adjudication the effect is an unconstitutional delegation of power to a private body. See Carter v. Carter Coal Co., 298 U.S. 238, 311 (1936); Schechter Poultry Corp. v. United States, 295 U.S. 495, 537 (1935); Eubank v. City of Richmond, 226 U.S. 137, 144 (1912). Cf. Lathrop v. Donohue, 367 U.S. 820, 854 (1961) (Harlan, J., concurring). But see St. Louis I.M. \& S. Ry. v. Taylor, 210 U.S. 281, 287 (1908); R.H. Johnson \& Co. v. SEC, 198 F.2d 690, 695 (2d Cir.), cert. denied, 344 U.S. 855 (1952); 1 K.C. Davis, ADministrative LAw Treatise § 2.14 (1958). The indirectness of the delegation plus the fact that the nondelegation doctrine is very much out of fashion as a constitutional principle, see generally id. \$ 2, suggest that this constitutional challenge would fail.

71 Building \& CONStr. Trades Dep'T, AFL-CIO, Plan for Settling Jurisdictional Disputes NATIONALly AND LOGALlY art. II, at 1 (April 1970). The presence of employer representatives on the Joint Board seems inconsistent with the premise of employer neutrality. See Plasterers, $63 \mathrm{CCH}$ Lab. Cas. I 10,993, at 19,191 (MacKinnon, C.J., dissenting).

72 Procedural Rules and Regulations of the National Joint Board for Settlement 
or agreements the award is determined by the established trade practice ${ }^{73}$ or the prevailing area practice. ${ }^{74}$ Obviously these criteria have little appeal to an employer whose work assignment is based on other considerations.

While Plasterers offers no real check on the authority of the Joint Board over important employer interests, the court appears to have hedged on its neutrality position somewhat by suggesting in a footnote that the decision might not apply in a case where the voluntary adjustment proceeding failed to make "realistic provision for meaningful attention to the interest of the employer, and to questions of efficiency."75 However, in the text to which the footnote refers, the opinion declares that the employer's interests are completely protected by speedy resolution of the controversy. Therefore, even if the court were willing to review the merits of such arbitration awards, it could not consistently deny preclusive effect to any voluntary adjustment proceedings that resulted in a final resolution of the dispute.

The NLRB provides a more sympathetic forum. In fact the great majority of $10(\mathrm{k})$ awards affirm the employer's assignment, ${ }^{76}$ thereby protecting the employer's interests.

In essence, then, any judgment as to the wisdom of the court's position regarding the NLRB policy must depend ultimately on whether union or employer interests are in greater need of protection. It could be argued that in the main industry in which the Joint Boards operate, the construction industry, the employers are the group to be favored. The employers are mostly small, marginal operators whose bargaining power relative to the unions is quite weak. ${ }^{77}$ As previously mentioned, changes in work assignment may spell the difference between profit and loss for these employers. Aside from the economic interests of the employers, a factor to be considered is the nature of the industry itself. In recent years the construction industry has been characterized by rapidly rising costs and low or nonexistent gains in productivity. ${ }^{78} \mathrm{~A}$ major rea-

of Jurisdictional Disputes, Procedures Used by the JoInt Board (B)(7)(a) $(1949$, as amended 1965).

$73 \mathrm{Id}$.

$74 \mathrm{Id}$.

7563 CCH Lab. Cas. ๆ 10,993, at 19,187 n.27.

76 See B. Meltzer, Labor Law: Cases, Materiats and Problems 547 (1970); O'Donoghue, supra note 12; Sussman, supra note 12. ABA LABOR ReLATIons SEction, SUPPLEMENTARY REPORT OF THE SPECIAL "IO(K)" CoMmtrteE 437, 498 (1964).

77 See The Wages of Building Zoom, Business WeEk, July 19, 1969, at 89-90; O'Hanlon, The Unchecked Power of the Building Trades, ForTune, Dec. 1968, at 102.

78 U.S. Dep't of Commerce, Business Statistics 78 (1969 ed.) (costs); U.S. Dep'T of ComMERCE, SURvey of CuRreNt Business S-15 (Nov. 1970) (costs); O'Hanlon, supta note 77, at 89-90. Givens, Job Security in the Building Industry-and High Quality Low-Rent Housing, 18 LAB. L.J. 468 (1967). 
son for the increased costs and the failure to introduce technological innovations has been the power of the building trades unions. ${ }^{79}$ In light of these considerations, one may question whether the Plasterers court was wise to break with long established practice in jurisdictional disputes, since the inevitable result is a further strengthening of the building trades unions.

79 Givens, supra note 78; O'Hanlon, supra note 77, at 103, 104, 209, 214. 